\title{
Huge Tongue Base Neurilemmoma : Excision by Intraoral Coblation
}

\author{
Jun Sun Kim, MD, PhanHuu Ngoc Minh, MD and Ki Hwan Hong, MD \\ Department of Otolaryngology-HNS, Institute for Medical Science, Chonbuk National University \\ Chonbuk National University Hospital, Chonbuk, Korea
}

\begin{abstract}
- ABSTRACT -
Neurilemoma arising from the tongue base are very rare and only a few cases have been reported so far. The tumor is resistance to radiotherapy, and therefore, the treatment of choice is surgery. Diagnosis was confirmed by imaging studies and biopsy followed by surgical excision designed to preserve nerve function. We report a case of huge neurilemoma of the tongue base treated with intraoral coblation. Case reports and a review of the world literature concerning treatment methods and surgical approaches of neurilemoma of tongue base. A number of surgical approaches have been described for tongue base neurilemomas. We report a case of tongue base neurilemoma which was completely extirpated with a coblation through the intraoral approach. The postoperative course was uneventful and improved within 2 weeks like as tonsillectomy patient. The intraoral coblation assisted excision is a safe and useful surgical technique for the removal of tongue base neurilemoma. (J Clinical Otolaryngol 2016;27:384-387)
\end{abstract}

KEY WORDS : Tongue $\cdot$ Neurilemmoma $\cdot$ Electrocoagulation $\cdot$ Oral surgical procedures.

\section{Introduction}

Neurilemoma or schwannoma is a benign encapsulated peripheral tumor of neuroectodermal derivation that originates from the Schwann cells of the neural sheath of motor and sensory peripheral nerves. Neurilemoma account for just over $1 \%$ of benign tumors reported in the oral cavity and the tongue is unanimously considered the most frequent site. ${ }^{1)}$ Neurilemoma arising from the tongue base are very rare and only a few cases have been reported so far.

The tumor is resistance to radiotherapy and the treatment of choice is surgery. A number of surgical ap-

논문접수일 : 2016년 8월 22일

논문수정일 : 2016년 9월 30일

심사완료일 : 2016년 11월 8일

교신저자 : 홍기환, 54907 전북 전주시 덕진구 건지로 20

전북대학교 의과대학 전북대학병원 이비인후과학교실

전화 : (063) 250-1990·전송: (063) 250-1986

E-mail:khhong@chonbuk.ac.kr proaches have been described for the tongue base neurilemoma. ${ }^{2-8)}$ Each has its own degree of postoperative morbidity. There are two reports about using laser for the tongue base neurilemoma.

We present a case of the tongue base neurilemoma which was completely extirpated with a coblation via the intraoral approach. The patient experienced virtually no morbidity from the use of coblation. We could not find an earlier report in the English literature describing our method of treatment. We suggest that intraoral coblation can be added to the surgical armamentarium for the management of other similar cases in the future.

\section{Case Report}

A 35 year-old female patient was presented with an eighteen-month history of slowly growing mass at the back of the tongue. She had symptoms of mild dysphagia, muffled voice and globus hystericus. Her medical history and family history were nonspecific. 
Fiberoptic nasopharyngoscopy revealed a large, mobile, and hard mass of the tongue base, obstructing almost completely the oropharynx and part of the supraglottic area. There was no palpable lymph node enlargement on the neck.

Blood investigations and biochemical analysis including thyroid stimulation hormone (TSH), triiodothyronine (T3) and thyroxine (T4) were within normal range.

Preoperative MRI scan of the neck showed a welldefined round heterogenous mass lesion measuring 4 $\times 3 \times 5 \mathrm{~cm}$ with smooth margins in the oropharynx extending from the uvula superiorly and up to the level of epiglottis inferiorly. It abutted the base of tongue on anterior and posterior pharyngeal wall on posterior (Fig. 1).

The patient was taken to the operating room for removal of the tongue base mass through an intraoral approach with coblation. After induction, the nasotracheal intubation was guided with a fiberloptic bronchoscope passed through the tube. With the patient in supine, head hanging position on the operating table, exposure was obtained by opening the Crowe-Davis mouth gag to expose the oropharynx (like tonsillectomy). At this time, we used a short tongue retractor to compress the anterior two third of the tongue for exposure of the tongue base. And the first assistant compressed the hyoid bone area of anterior neck to expose the tongue base wider. A throat pack used to prevent blood and secretions from entering the esophagus. At this point, the dissection of tongue base mass is performed with coblation. The mass is grasped with a hemostat ant then retracted posterior, and the anterior border of mass is dissected with coblation. We performed an intraoral excision of the mass, which presented a well-delineated plan separating it from the surrounding tongue muscles (Fig. 2). After removal of the tumor, meticulous hemostasis was performed with coblation. As noted, procedure is similar to the standard tonsillectomy but with pay more attention to airway and bleeding. The wound of tongue base was not closed like as tonsillectomy. Postoperatively, The base of tongue shows normal appearance (Fig. 3)

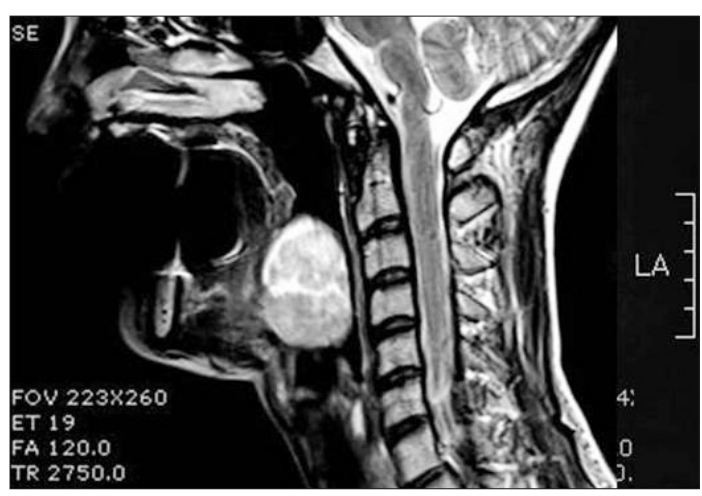

Fig. 1. Preoperative MRI scan of the neck showed a well-defined round heterogenous mass lesion measuring $4 \times 3 \times 5 \mathrm{~cm}$ with smooth margins in the oropharynx extending from the uvula superiorly and up to the level of epiglottis inferiorly.
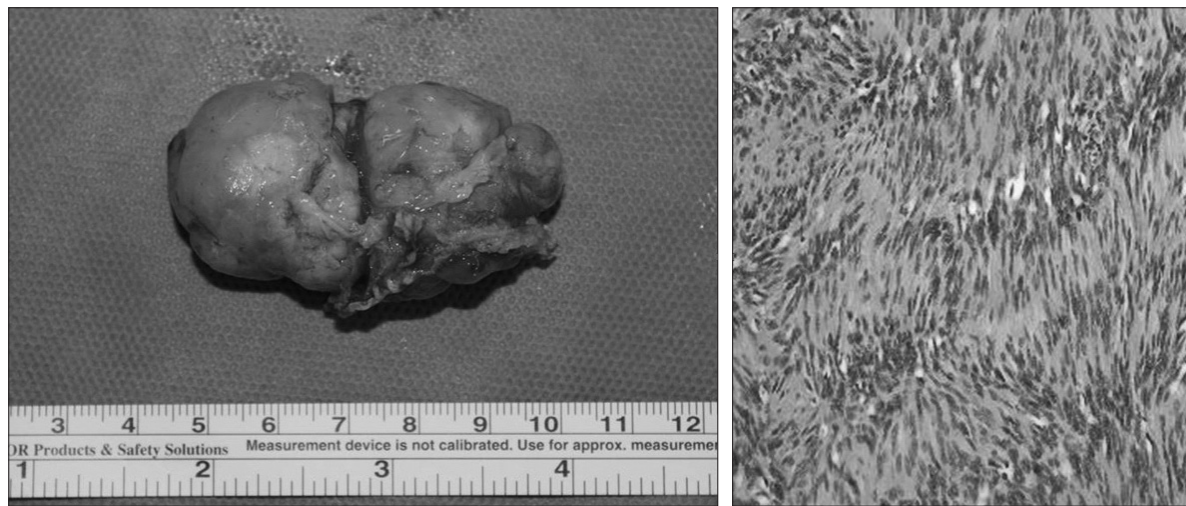

Fig. 2. Photograph shows a soft mass measuring $4 \times 3 \times 5 \mathrm{~cm}$ with well circumscribed \& Neurilemmoma with palisading of the cells $(H \& E, \times 250)$. 


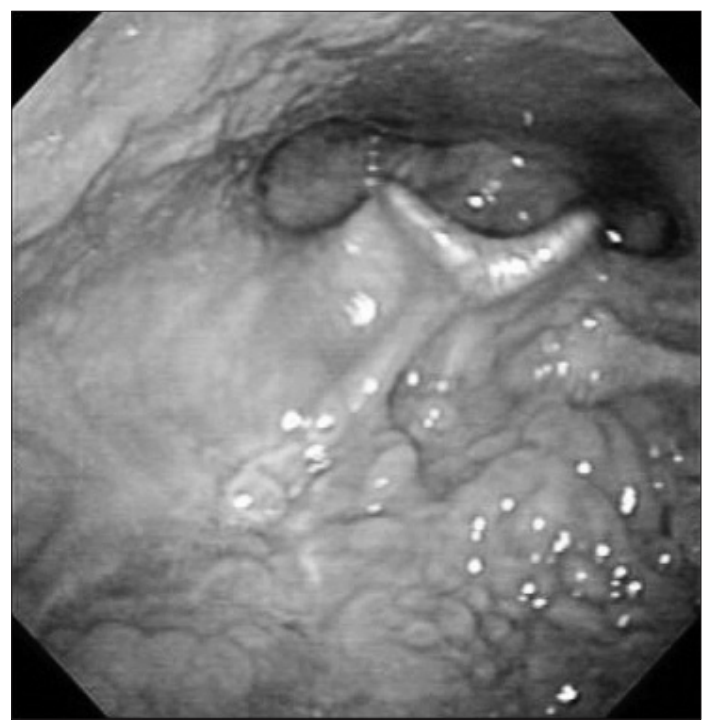

Fig. 3. Photogragh shows no-mass on the base of tongue.

No primary nerve originating this lesion was macroscopically identified during surgery. The patient was immediately extubated, with an uneventful postoperative course. Microscopic examination revealed a typical histology of neurilemoma composed of alternating regions consisting of compact spindle cells called Antoni A areas, and loose, hypocellular zones called Antoni B areas.

\section{Discussion}

The tongue is the most common location for intraoral neurilemoma, followed by the palate and the oral mucosa. Tongue neurilemoma shows no gender predilection and may present at any age (especially in the third decade of life). Often appearing as a painless and slowly enlarging mass of the tongue, when neurilemoma reach a certain size they may cause dysphagia, voice chages, and breathing difficulties. ${ }^{2)}$ Our patient had the symptoms of dysphagia, voice change, and lump sensaion.

The etiology is unknown and the tumor is usually solitary. Multiple lesions may occur in association with Von Recklinghausen's disease or Schwannomatosis, a nonhereditary disease characterized by multi- ple subcutaneous or intradermal neurilemoma together with tumors of internal organ. ${ }^{7}$

Radilogical exam permit to assess the extension of the lesion, and they are useful as preoperative workup. Magnetic resonance imaging is the bast exam to show deep lesions of tongue base soft tissues. Even if a certain number of particular features are found in the imaging of neurilemoma, none is specific. ${ }^{10)}$

The differential diagnosis includes benign lesions such as granular cell tumors, leiomyoma, lymphangima, lipoma, lingual thyroid, and malignant lesions like squamous-cell carcinom, cancer of salivary glands, and soft tissue sarcoma. The final diagnosis is always made after a difinitive histological examination. ${ }^{7}$

Treatment of neurilemoma of the tongue is surgical. The goal of surgical therapy is to complete resection. The most common approach is the transoral route. A transoral approach for oral tongue allows us to completely remove even the largest lesions, with a very low rate of morbidity and recurency. ${ }^{2)}$

A number of surgical approaches have been described for tongue base neurilemoma. There is one report about submandibular approach for tongue base neurilemoma. ${ }^{5}$ The submandibular approach allows an excellent exposure of the base of tongue with less obvious scar than a lip-splitting incision. Sawhney et al. described a unilateral transcervical incision with blunt dissection for tongue base neurilemoma. This approach is simple and quickly accomplished with protection of nearby nerves. ${ }^{9)}$ More recently, the use of carbon dioxide laser for excision of a base of tongue neurilemoma has been reported. ${ }^{3,4)}$ They completely removed the tongue base tumor with carbon dioxide laser via the transoral approach.

Coblation has been used in various otolaryngologic procedures on a regular basis for many years. These procedures include adenotonsillectomy, turbinate reduction, and tongue base and soft palate sleep apnea procedures, laryngotracheal respiratory papillomatosis, vallecular cysts, and selected upper aerodigestive tract malignancies. Coblation produces a localized, high-energy plasma field that ablates tissue and seals 
blood vessels simultaneously. It works at temperatures of $40-70{ }^{\circ} \mathrm{C}$, which is significantly lower than the monopolar cautery and $\mathrm{CO} 2$ laser, thus may reduce collateral tissue damage and less invasive. ${ }^{11)}$ So, this procedures are good to control of bleeding during operation, and decreases postoperative complications such as pain or edema.

Other surgical options for treatment of tongue base tumor include tongue-splitting for trans-oral excision, peroral approach via a mandibular midline osteotomy, suprahyoid pharyngotomy, ${ }^{7)}$ transhyoid approach, ${ }^{8)}$ and lateral pharyngotomy. All of these ap-proaches need tracheotomy and intensive cares unit for airway problem.

The main disadvantage of transoral removal with coblation for tongue base tumor is limited exposure. It is related to patient anatomy and the volume of tongue and mass. We could establish wider operation field to use the shorter tongue depressor and counter compression of tongue base by assistant. We didn't use any electrocautery during tumor dissection.

In conclusion, the intraoral removal of tongue base neurilemoma with coblation is a simple, reliable and should be considered as an alternative method in the management of tongue base tumor.

\section{REFERENCES}

1) Callesio C, Berrone S. Schwannoma located in the tongue: a clinical case report. Minerva Stomatol 1992;41(12):58390.

2) Cohen M, Wang MB. Schwannoma of the tongue: two case reports and review of the literature. Eur Arch Otorhinolaryngol 2009;266(11):1823-9.

3) Ballesteros F, Vilaseca I, Blanch JL, Gaspa A, BernalSprekelsen M. Base of tongue neurilemmoma: excision by transoral laser microsurgery. Acta Otolaryngol 2007;127(9): 005-7.

4) Mehrzad H, Persaud R, Papadimitriou N, Kaniyur S, Mochloulis G. Schwannoma of tongue base treated with transoral corbon dioxide laser. Lasers Med Sci 2006;21(4): 235-7.

5) de Bree R, Westerveld GJ, Smeele LE. Submandibular approache for excision of a large schwannoma in the base of tongue. Eur Arch Otorhinolaryngol 2000;257(5):283-6.

6) Sawhney R, Carron MA, Mathog RH. Tongue base schwannoma: report, review, and unique surgical approach. Am J Otolaryngol 2008;29(2):119-22.

7) Ying Y-LM, Zimmer LA, Myers EN. Base of tongue schwannoma: a case report. Layngoscope 2006;116(7):1284-7.

8) Hsu YC, Hwang CF, Hsu RF, Kuo FY, Chen CY. Schwannoma (neurilemmoma) of the tongue. Acta Otolaryngol 2006;126(8):861-5.

9) Spandow O, Fagerlund M, Bergmark L, Boquist L. Clinical and histopathological features of a large parapharyngeal neurilemmoma located at the base of tongue. ORL $J$ Otorhinolaryngol Relat Spec 1999;61(1):25-30.

10) Nisa L, von Buren, Tiab A, Giger R. Giant plexiform schwannoma of the tongue. Case Rep Otolaryngol 2011;2011:762524.

11) Judd H. Fastenberga, Soham Royb, Lee P. Smitha. Coblation-assisted management of pediatric airway stenosis. Int J of Pediat Otorhinolaryngol 2016;87(1):213-8. 